\title{
Article \\ Conceptualization and Realization of a National Trail in a Small Island-Nation: The Commonwealth of Dominica's Experience
}

\author{
Colmore S. Christian
}

check for

updates

Citation: Christian, C.S.

Conceptualization and Realization of a

National Trail in a Small Island-Nation

The Commonwealth of Dominica's

Experience. Tour. Hosp. 2021, 2, 79-94. https://doi.org/10.3390/tourhosp 2010005

Received: 29 December 2020

Accepted: 27 January 2021

Published: 30 January 2021

Publisher's Note: MDPI stays neutral with regard to jurisdictional claims in published maps and institutional affiliations.

Copyright: (c) 2021 by the author Licensee MDPI, Basel, Switzerland. This article is an open access article distributed under the terms and conditions of the Creative Commons Attribution (CC BY) license (https:// creativecommons.org/licenses/by/ $4.0 /)$
Forestry, Ecology and Wildlife Program, College of Agricultural, Life and Natural Sciences, Alabama A\&M University, Normal, AL 35762, USA; colmore.christian@aamu.edu

Abstract: The island-nation of Dominica, $790 \mathrm{~km}^{2}$ in area, is located approximately $1126.5 \mathrm{~km}$ Southeast of Florida, USA. In the mid-1990s, Dominica embarked on developing the $183.5 \mathrm{~km}$ Waitukubuli National Trail (WNT), the first and only national trail model in the Eastern Caribbean. The 14-segment WNT, officially opened in May 2013, passes through some of the island's most diverse landscapes. WNT was designed to link as many rural communities as possible and promote ecotourism and community socioeconomic development. Rehabilitation work continues on the WNT and the rest of Dominica, following the devastation caused by Hurricane Maria of 2017. This article, based primarily on a limited questionnaire survey, selected interviews, and literature review, explored the research question 'What were the challenges faced by a small-island nation in the development of a National Trail? Five specific research objectives focused on the conceptualization, implementation challenges, partnerships fostered, national and sub-regional significance, and future outlook of the Trail were considered. Questionnaire respondents identified the island's topography and negotiations with private landowners as significant trail construction challenges. A 100\% of survey respondents anticipate that reliable funding to support timely maintenance would likely be a critical future issue. Some respondents identified marketing, public engagement, and visitor safety as potential issues. Face-to-face interviews found strong support for the WNT. The interviewees were confident that Dominica would realize sustainable socioeconomic benefits from the Trail. The article concludes with lessons learned and proposes strategies and research themes to ensure the Trail's sustainability.

Keywords: Dominica; island; Caribbean; Waitukubuli National Trail; long-distance trail; nature tourism; ecotourism; sustainable development

\section{Introduction}

The Interagency Trail Data Standards Team in the United States of America (USA) defined a trail as "A linear route managed for human-powered, stock, or Off-Highway Vehicle [OHV] forms of transportation or for historical or heritage values" [1]. A nature trail, according to Douglass [2] " ... is a route designed to lead users to places where points of geological, biologic, historical, or cultural interest can be explained to them." Eyler et al. [3] presented a slightly different definition when they stated that a trail "... is a path used for non-motorized travel".

Long-distance trails (or long-distance tracks, paths, or greenways) in the United Kingdom (UK) are the longer recreational trails mainly through rural areas, used for nonmotorized recreational traveling (walking, backpacking, cycling, or horse riding). Typically, a long-distance trail will be at least $50 \mathrm{~km}$ long, but some UK trails are several hundreds of kilometers long [4]. Many trails in the USA are much longer. There was no evidence in the literature of the existence of long-distance or national trails on island developing nations.

The Interagency Team [1] has also recognized different categories of trails: 'Standard Trails', 'National Scenic Trails', and 'National Historic Trails'. These categories are somewhat similar to the three main categories_-'National Recreation Trails,' 'National Scenic 
Trails' and 'National Historic Trails' - identified under the USA's National Trails System Act of 1968. The fourth less popular category identified under the Act is the 'Connecting and Side Trail' [5]. In this article's context, the term 'trail' refers to a linear route developed to facilitate public access to natural, scenic, historical, and geological areas for educational, recreational, leisure, or inspirational purposes. The article's focus is on the Waitukubuli National Trail (WNT), which like many other national trails, is classified as a long-distance walking route through the best landscapes [6].

What were the challenges faced by a small-island nation in developing a National Trail? This was the research question considered in this study. More specifically, this analysis explored five objectives namely:

1. To determine the factors and considerations which influenced and contributed to the Trail's conceptualization;

2. To identify the critical support mechanisms and partnerships which had to be fostered to bring the Trail concept to reality;

3. To assess the national and sub-regional significance of the Waitukubuli National Trail;

4. To present lessons learned from this National Trail development initiative;

5. To propose management strategies and a research agenda likely to contribute to the sustainability and realization of anticipated long-term socioeconomic benefits of the Trail.

\section{Materials and Methods}

\subsection{The Study Site}

The Commonwealth of Dominica, hereafter referred to as Dominica, is the largest island of the Windward Islands sub-grouping. Sandwiched between two French overseas departments, Guadeloupe to the north and Martinique to the south, Dominica is centrally located in the Caribbean archipelago (Figure 1). The island's volcanic origins have resulted in the presence of a series of mountains, including some of the tallest peaks in the Eastern Caribbean. These mountains dominate the island's central ridge from north to south. A boiling lake, one of the largest of its kind in the world, warm springs, Sulphur vents, and two freshwater crater lakes are among the vivid reminders of Dominica's volcanic origins $[7,8]$.

This unique and rugged topography, in no small measure, is partly responsible for the relatively low level of infrastructural development on the island. Although the mountains may have hindered and slowed the infrastructural development rate, these mountains contribute to the varied and outstanding natural landscapes, diversity of ecological zones, and the abundance of continuously flowing streams and rivers on the island. A network of hiking trails, dispersed throughout the island's national park and forest reserve system, was developed to support the island's ecotourism thrust.

Dominica's $183.5 \mathrm{~km}$ Waitukubuli National Trail (WNT), constructed over approximately nine years, traverses the entire length of the island, stretching from the northern rural community of Capuchin to the southern community of Scotts Head [10]. This long construction period is not unusual for such trails, according to Eyler et al. [3]. The 14segment WNT was designed to link as many communities as possible (Figure 2, Table 1). 


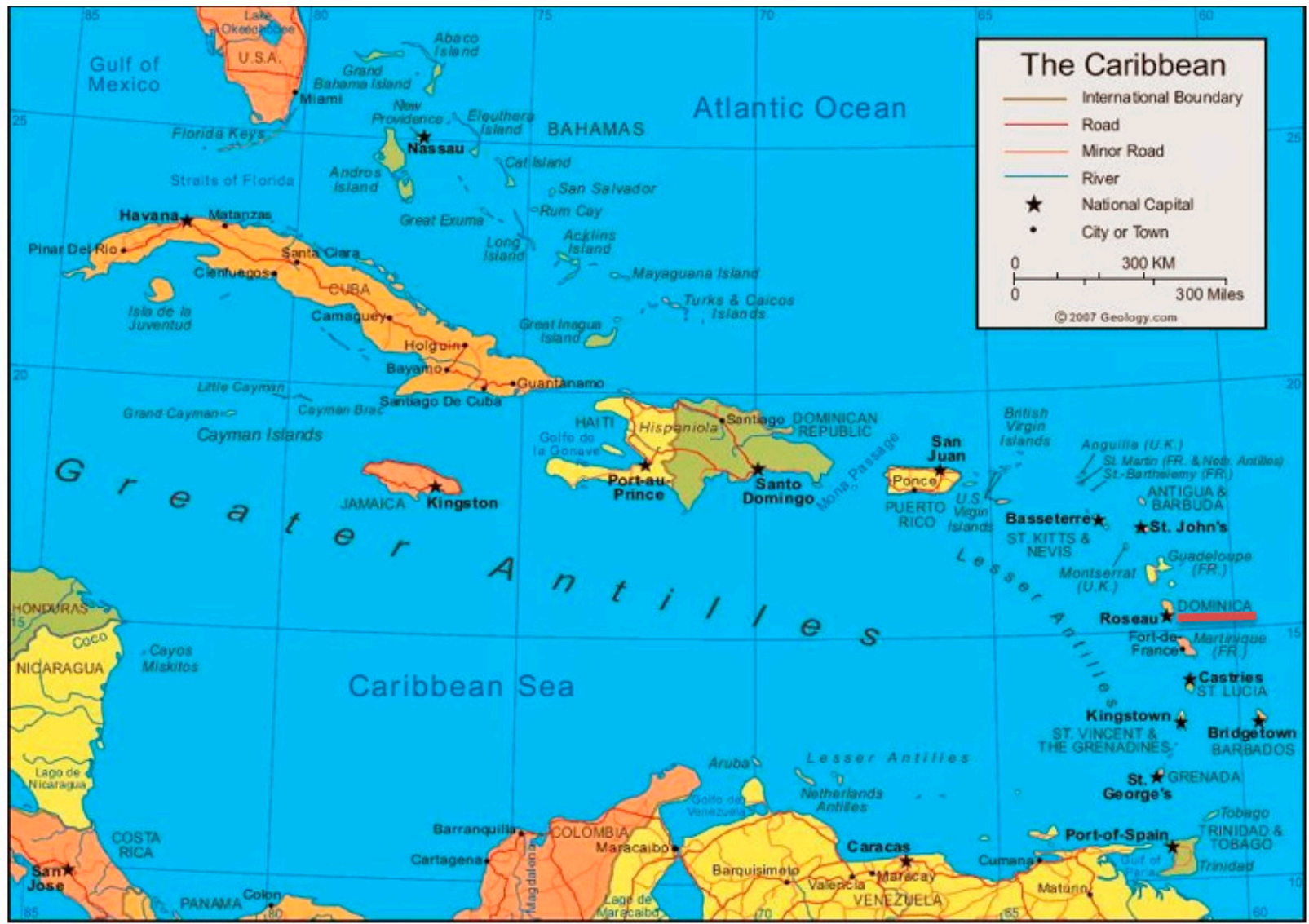

Figure 1. The geographic location of Dominica [9].

Table 1. The Waitukubuli National Trail's 14 segments [12].

\begin{tabular}{|c|c|c|c|c|}
\hline Segment & Trail & Distance & $\begin{array}{l}\text { Estimated } \\
\text { Time }\end{array}$ & Level \\
\hline 1 & $\begin{array}{l}\text { Scotts Head to Soufriere } \\
\text { Estate with Accommodation }\end{array}$ & $7 \mathrm{~km}$ & $5.5 \mathrm{~h}$ & $\begin{array}{l}\text { Easy hike, } \\
\text { Family hike }\end{array}$ \\
\hline 2 & $\begin{array}{l}\text { Soufriere Estate to Bellevue } \\
\text { Chopin with Accommodation }\end{array}$ & 10.8 km & $6.5 \mathrm{~h}$ & Moderate hike \\
\hline 3 & $\begin{array}{l}\text { Bellevue Chopin to Wotten } \\
\text { Waven with Accommodation }\end{array}$ & $14.9 \mathrm{~km}$ & $7 \mathrm{~h}$ & Moderate hike \\
\hline 4 & $\begin{array}{l}\text { Wotten Waven to Pond Casse } \\
\text { with Accommodation }\end{array}$ & $11.7 \mathrm{~km}$ & $6 \mathrm{~h}$ & $\begin{array}{l}\text { Moderate hike, } \\
\text { Nature lovers }\end{array}$ \\
\hline 5 & $\begin{array}{l}\text { Pond Casse to Castle Bruce } \\
\text { with Accommodation }\end{array}$ & $12.8 \mathrm{~km}$ & $7 \mathrm{~h}$ & $\begin{array}{l}\text { Easy hike, } \\
\text { Family hike }\end{array}$ \\
\hline 6 & $\begin{array}{l}\text { Castle Bruce to Hatton } \\
\text { Garden with Accommodation }\end{array}$ & $15 \mathrm{~km}$ & $7 \mathrm{~h}$ & Moderate hike \\
\hline 7 & $\begin{array}{l}\text { Hatton Garden to First Camp } \\
\text { with Accommodation }\end{array}$ & $12.6 \mathrm{~km}$ & $6 \mathrm{~h}$ & $\begin{array}{c}\text { Moderate hike, } \\
\text { Nature lovers }\end{array}$ \\
\hline 8 & $\begin{array}{l}\text { First Camp to Petite } \\
\text { Macoucherie }\end{array}$ & $10 \mathrm{~km}$ & $6 \mathrm{~h}$ & $\begin{array}{l}\text { Strong hikers } \\
\text { who are well } \\
\text { trained }\end{array}$ \\
\hline 9 & $\begin{array}{l}\text { Petite Macoucherie to } \\
\text { Colihaut Heights with } \\
\text { Accommodation }\end{array}$ & $9.8 \mathrm{~km}$ & $7 \mathrm{~h}$ & $\begin{array}{l}\text { Hard hike, } \\
\text { Nature lovers }\end{array}$ \\
\hline
\end{tabular}


Table 1. Cont.

\begin{tabular}{ccccc}
\hline Segment & Trail & Distance & $\begin{array}{c}\text { Estimated } \\
\text { Time }\end{array}$ & Level \\
\hline 10 & Colihaut Heights to Syndicate & $6.4 \mathrm{~km}$ & $4 \mathrm{~h}$ & $\begin{array}{c}\text { Easy hike, } \\
\text { Family hike }\end{array}$ \\
\hline 11 & $\begin{array}{c}\text { Syndicate to Borne with } \\
\text { Accommodation }\end{array}$ & $10 \mathrm{~km}$ & $7 \mathrm{~h}$ & $\begin{array}{c}\text { Hard / long hike, } \\
\text { Suited for nature } \\
\text { lovers }\end{array}$ \\
\hline 12 & Borne to Penville (Delaford) & $9.5 \mathrm{~km}$ & $7 \mathrm{~h}$ & $\begin{array}{c}\text { Difficult and } \\
\text { long hike }\end{array}$ \\
\hline 13 & Penville to Capuchin & $8 \mathrm{~km}$ & $3.5 \mathrm{~h}$ & Moderate hike \\
\hline 14 & $\begin{array}{c}\text { Capuchin to Cabrits National } \\
\text { Park with Accommodation }\end{array}$ & $10.8 \mathrm{~km}$ & $5 \mathrm{~h}$ & Moderate hike \\
\hline
\end{tabular}

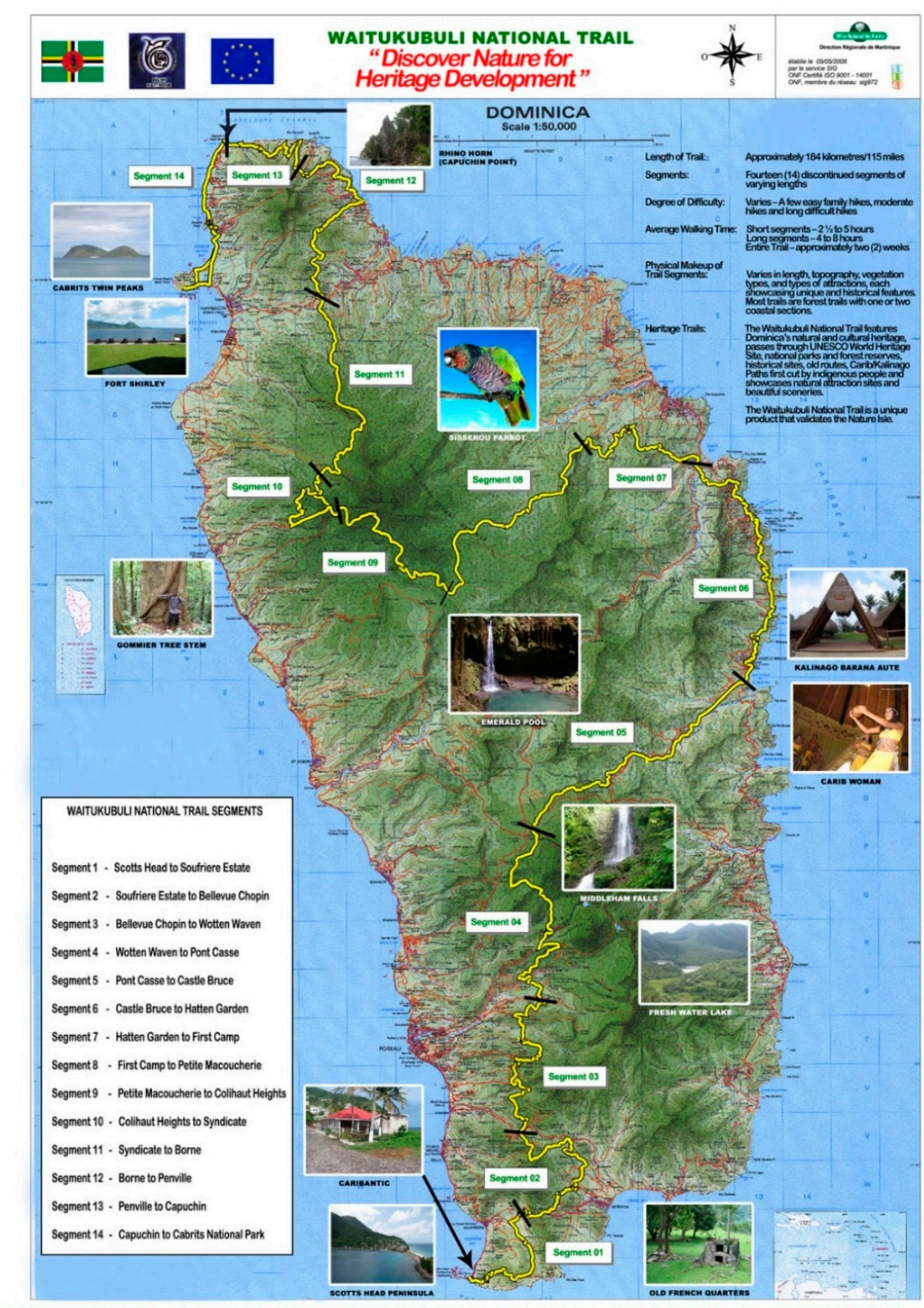

FUNDED BY THE EUROPEAN UNION AND THE GOVERNMENT OF THE COMMONWEALTH OF DOMINICA AND IMPLEMENTED IN PARTNERSHIP WITH THE REGIONAL COUNCIL OF MARTINIQUE

Figure 2. The alignment of Dominica's Waitukubuli National Trail [11]. 
The Eastern Caribbean's first national hiking trail became a reality as a result of the vision, collaboration, and financial support of the Waitukubuli Ecological Foundation (WEF), the European Union (EU), the Regional Council of Martinique, the Government of Dominica, and a few other stakeholders.

\subsection{Methods}

This study is based primarily on a limited questionnaire survey and on the results of interviews with a few persons who were directly or indirectly associated with the project, in different capacities. These sources were supplemented by the author's knowledge and literature review. Consequently, there are no statistical analyses. In 2014, a nine-question survey instrument (Appendix A) was used to solicit information from a small target group. The group consisted of two technicians who coordinated and supervised WNT construction activities, the individual who conceptualized the project, and the Forestry and Wildlife Division (FWD) - the state's agency with direct responsibility for trail development and management on the island. In addition, face-to-face, structured interviews were held in 2014 with the individual who conceptualized the project, the two technicians referenced above, one representative from each of the following stakeholder groups: Discover Dominica (the tourism agency), tour guides, hoteliers, and taxi operators. The purpose of the interviews was to gain insights into the representative's thinking and perspectives regarding the challenges and potential benefits of the National Trail.

\section{Results}

\section{Conceptualization of Dominica's Waitukubuli National Trail}

Based on interviews and literature review, it was established that in 1993, Bernard Wiltshire, then President of WEF, formally introduced and publicized the Waitukubuli National Trail development idea. According to Wiltshire, the WNT concept was motivated by his years of experience living in the UK, where long-distance trails are top-rated and well supported. Wiltshire stated that the National Trail was initially conceived as a 'millennium project,' hoping it would have been completed by 2000. The Trail was meant to be a project of all the people (i.e., 'an enterprise of the people') to signal a national renewal at the start of the new century and millennium and embody the concept of national purpose or national mission, Wiltshire disclosed. This proposed trail project, it was also stated, " ... would give practical expression to the concept of sustainable tourism or ecotourism, because its appeal would primarily be to the sort of visitors who love and respect the natural environment and are passionate about its conservation while contributing to its economic development" [13].

The specific objectives of the WNT, as perceived by WEF and outlined in CANARI [14], were:

- "To enhance and significantly transform the tourism product of Dominica and increase its marketability and competitiveness, resulting in quantitative and qualitative improvements in the impacts of tourism on economic development at the national and local levels;

- To promote and support rural development, with special emphasis on the needs of poor and marginalized communities;

- To provide a focus for the strengthening of social capital, for the development of national pride and identity, and community cohesion and unity;

- To provide a source of recreation and enjoyment for all Dominicans; and

- To encourage, promote, and valorize environmental conservation and sustainable development at all levels".

In support of these objectives, the development and management of the National Trail were to be guided by principles and criteria focusing on environmental integrity, economic impact, geographic distribution, inclusivity, diversity, heritage, feasibility, effective management, participatory, and sustainability [14]. 
Three of the four respondents to the questionnaire survey identified the island's topography and negotiations with private landowners among the major challenges which had to be addressed during trail construction. All four respondents anticipated that reliable funding to support timely maintenance as a possible future challenge. In contrast, one respondent identified the need for marketing and public engagement as being critical future issues (Table 2).

Table 2. Summary of responses to questionnaire survey sample questions.

\begin{tabular}{|c|c|c|c|c|}
\hline Survey Question & Respondent A & Respondent B & Respondent C & Respondent D \\
\hline \multicolumn{5}{|c|}{ Q\#6: What were the three most important challenges experienced during trail construction? } \\
\hline & - Challenging terrain & $\begin{array}{c}\text { - High-jacking of } \\
\text { project by Government }\end{array}$ & $\begin{array}{l}\text { - Limited project } \\
\text { personnel }\end{array}$ & -Rough terrain \\
\hline & $\begin{array}{l}\text { - Landowners } \\
\text { negotiations }\end{array}$ & $\begin{array}{l}\text { - Implementation } \\
\text { strategy }\end{array}$ & $\begin{array}{l}\text { - Landowner } \\
\text { negotiations }\end{array}$ & $\begin{array}{l}\text { - Engagement of } \\
\text { landowners }\end{array}$ \\
\hline & $\begin{array}{c}\text { - Delay in submission } \\
\text { of re-imbursement } \\
\text { claims }\end{array}$ & $\begin{array}{l}\text { - Poor policy } \\
\text { framework }\end{array}$ & - Difficult terrain & - Project funding \\
\hline \multicolumn{5}{|c|}{ Q\#7: What are the most critical challenges experienced since the official opening of WNT? } \\
\hline & $\begin{array}{l}\text { - Maintenance } \\
\text { (financing \& terrain) }\end{array}$ & - Maintenance & -Maintenance & - Maintenance \\
\hline & $\begin{array}{l}\text { - Standardization of } \\
\text { products \& services }\end{array}$ & $\begin{array}{l}\text { - Poor marketing and } \\
\text { promotion }\end{array}$ & - Long-term funding & - Funding \\
\hline & $\begin{array}{l}\text { - Monitoring of ticket } \\
\text { vendors' sales }\end{array}$ & $\begin{array}{l}\text { - Lack of public } \\
\text { engagement }\end{array}$ & - Visitor safety & -Personnel \\
\hline \multicolumn{5}{|c|}{ Q\#9: How is the management and maintenance of the WNT currently financed? } \\
\hline & $\begin{array}{c}\text { National treasury \& } \\
\text { User fees }\end{array}$ & National treasury & National treasury & National treasury \\
\hline
\end{tabular}

There were deviations from the initial National Trail concept during project implementation, the interviews revealed. One such deviation was concerning the National Trail's alignment. During the project's initial planning phases, there was general agreement that sections of farm/agricultural access roads could be included in the trail's alignment. However, primary roads were to be avoided as much as possible [14]. Long stretches of primary roads were included in the final trail design because of technical challenges experienced during project implementation. Consequently, the inclusion of some 'historical trail' sections was not possible. Some of these 'historical trail' sections were used by the island's initial inhabitants, the Kalinago people (Caribs), and rural residents prior to the development of the current motorable road network on the island.

Face-to-face interviews ascertained strong support for the development of the National Trail. All seven interviewees were confident that Dominica would realize sustainable social and economic benefits from the trail. They all committed, both individually and through their organizations, to do whatever possible to support the National Trail initiative.

\section{Discussion}

As part of securing the necessary funding, the Government of Dominica took over the coordination and management of all aspects of the Trail project in 2005, despite the vocal objections of WEF. Consequently, the National Trail project's initial advocates were sidelined during the final planning and implementation stages, leading to deviations from some of the fundamental principles advanced during the conceptualization phase. For example, no user fees were envisaged by the Trail's initial proponents for the primary reasons of ensuring and promoting public support for the Trail from locals and visitors alike. It was anticipated that the overall social and economic benefits generated in communities adjacent 
to the WNT and the country would more than compensate for the Trail's maintenance and operational costs, which were to be funded from the island's treasury. However, this element of the initial National Trail concept failed to win the Government's support. A fee structure was introduced on 1 July 2013, a little less than one month after the 10 May 2013 Grand Opening Ceremony of the WNT. Four of the 14 Trail segments were opened to the public in 2011 before the official opening.

In 1997, Dominica's Government implemented a user fee system for the island's major ecotourism sites [15]. Against this background, the relevant natural resource and tourism management agencies on the island and the political directorate would have had much difficulty in justifying or accepting the idea of exempting the National Trail, the island's flagship trail, from the user fee system.

Consequently, the WNT was added to the list of ecotourism sites under the FWD's management. As a result of this ecotourism designation, 'all tourists/visitors and nonresidents' must obtain a trail pass (ticket) to access/hike the National Trail. Three categories of WNT access passes are available, according to FWD:

1. Day Pass: for US\$12.00 (EC \$32.04). May be used to visit several sites.

2. Special Pass: for US $\$ 10.00$ (EC $\$ 26.70)$. May be used to access several sites in one (1) day. Targeted at cruise ship passengers on organized tours.

3. Fifteen Day Pass: for US\$40.00 (EC $\$ 106.80)$.

In addition, stayover visitors can purchase site passes at the cost of US\$5 (EC \$13.35) each. Site passes are used to access specific ecotourism sites. Passes to all ecotourism sites including WNT can be purchased at outlets, such as at the Waitukubuli National Trail Management Headquarters, the FWD, and vendors throughout the island (Figure 3). The requirement that hikers should register with FWD or WNT Management Headquarters before embarking on hikes of the WNT and some of the other taxing ecotourism trails such as the Boiling Lake Trail is considered a critical visitor safety measure, according to FWD officials.

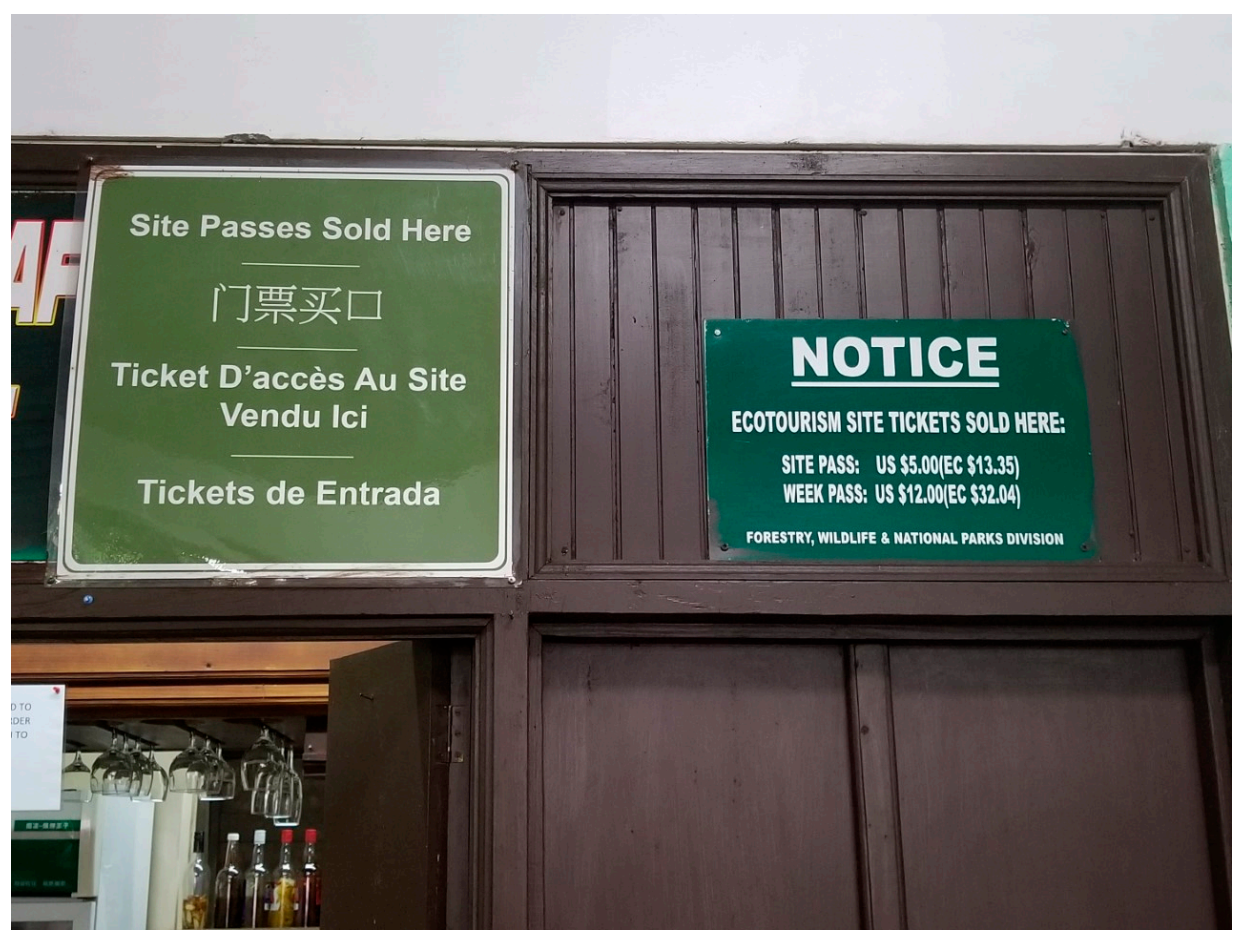

Figure 3. An ecotourism site pass sales outlet located at the Emerald Pool concession booth in the Morne Trois Pitons National Park and World Heritage Site (Photograph: complements of Carlyon Christian). 


\subsection{Soliciting Support and Building Partnerships for the WNT Project}

It was challenging to convince the Dominican authorities and the local population of merits and potential benefits of a National Trail. Through its then President Wiltshire, WEF shared its vision for the National Trail and its perception of the long-term national socioeconomic impact message to the local media and civil society groups island-wide. For a couple of years, WEF was the 'lone voice and face' of the proposed National Trail. Awareness building on the local front was slow; however, WEF was not daunted and persevered. Overall, WEF invested much time and energy in sensitizing the general public and potential strategic partner-agencies such as the FWD, the National Development Cooperation (the predecessor to Discover Dominica), the Dominica Chamber of Commerce, the Dominica Hotel and Tourism Association, and technocrats in relevant Government departments about the project. Given the National Trail's proposed alignment, the FWD was a vital ally considering that much of the public lands along which the Trail was likely to traverse were managed by FWD. Furthermore, most of the locally-based trail development, maintenance, and management expertise and experience rest within that agency.

Securing funding for such a venture was another major hurdle to be overcome. While efforts to promote the project's concept locally was critical and ongoing for several years, efforts to secure tangible support for the project from external sources were simultaneously pursued. Regional and international partnerships were cultivated over an extended period, eventually resulting in funding being made available by the British Development Department (BDD) for a national trail feasibility study. This funding level, the President of WEF noted, "was a significant accomplishment and breakthrough and helped to convince many Dominicans of the project's potential and demonstrated external support for the initiative". The Trinidad and Tobago-based Caribbean Natural Resources Institute (CANARI) was the consultant engaged to conduct the feasibility study. As part of the study, a one-day stakeholders' workshop was convened on the island in 1998 to gauge stakeholders' support and capture some of the essential conceptual elements of the proposed national trail. Workshop participants overwhelmingly endorsed the National Trail concept and committed to working towards its realization, the interview with WEF's President revealed.

The feasibility study concluded that the project was feasible and could realize a wide range of social and economic benefits. Very importantly, the report highlighted the potential contribution of a National Trail to community and rural development in Dominica. The report outlined preliminary development plans for the project, projected estimated construction costs, proposed implementation and management structure, and identified possible funding sources and revenue streams [14]. That document was a handy tool for advancing the overall discussion about the potential national trail.

Given the importance of nature tourism to the national economy $[7,16]$ and the convincing arguments presented in the Feasibility Study Report, the Government of Dominica officially embraced the national trail concept. The Government began to engage WEF in a meaningful way, discussing strategies to help make the project a reality. The next challenge which had to be addressed was to secure the estimated US\$6 million (EC\$16 million) required to implement the project.

Dominica did not have the financial resources to fund the construction of the WNT. Consequently, securing external support was a significant hurdle. Following the feasibility study's completion, the WEF approached the European Union's (EU) office in Barbados for financial support. The EU indicated a willingness to fund the project under a special funding assistance program, which would only be available on the Government's application. The EU advised the WEF to seek the Government's interest in applying for funding under this unique funding mechanism. Based on this WEF initiative, the Government negotiated and secured approximately $95 \%$ of the projected costs as grant funds from the EU. The Regional Council of Martinique contributed an additional 5\% of the required funding.

WEF's perspectives, conceptual framework for project implementation, and longterm project management strategies were not always aligned with those of the Govern- 
ment. These disagreements eventually led to the souring of relations between WEF and the Government.

The WNT's alignment traverses challenging terrain-deep gorges, river crossings, ridges, and mountains. According to the technicians, the transportation of construction tools and equipment and building materials, where necessary, proved very demanding. The contractor had to be very creative in trying to address these challenges. Furthermore, a significant portion of the WNT crosses private lands. Thus, as an initial critical step, the Government had to secure 'right-of-way access' across these private lands. The Government employed a mix of strategies to secure private landowners' agreements. In this regard, sensitization meetings with affected landowners were essential in securing private landowners' signatures on 'Ease of Access Forms' with the Government. In one case, the Government bought the property, whereas, in some cases, affected landowners accepted compensation, at market value, for crops and forest trees damaged during trail construction on their properties. In a few cases, affected landowners agreed to some form of co-management of facilities (e.g., birdwatching towers, restrooms, directional signs, and rain/picnic shelters [Figure 4]) located on their properties. Co-management arrangements presented opportunities for the participating landowner to develop creative income generating, WNT user-related services on her/his property. Based on experiences in other countries, it is perceived that the presence of the WNT could potentially contribute to increased property values in the vicinity of the Trail [3].



(A)

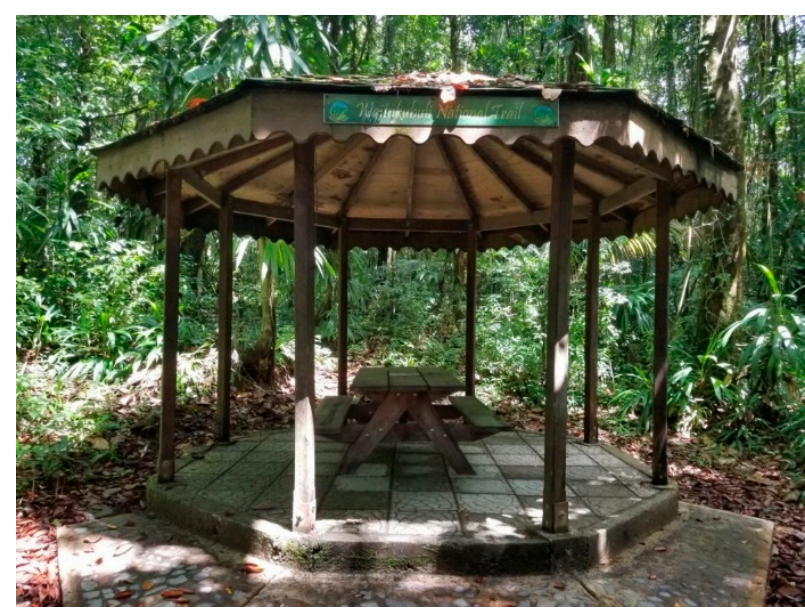

(B)

Figure 4. Cont. 


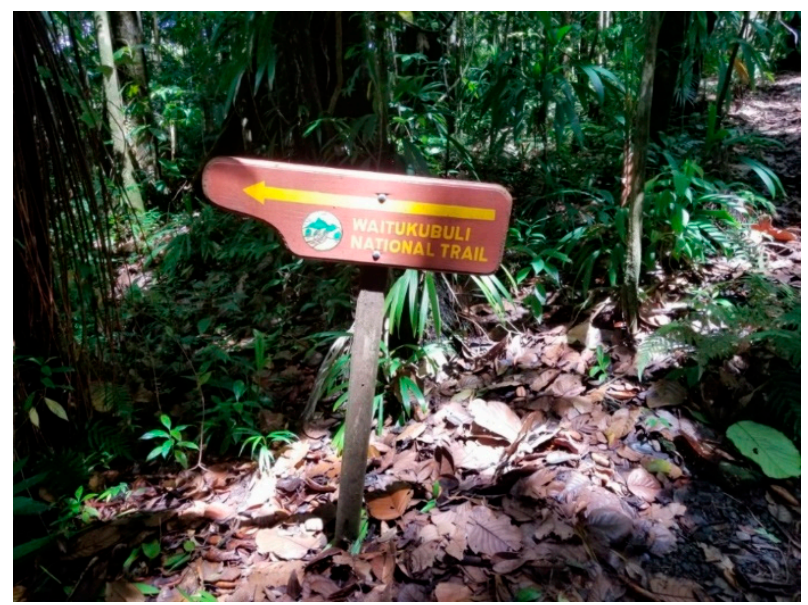

(C)

Figure 4. A selection of facilities provided along the WNT: $(\mathbf{A}, \mathbf{B})$ reflect different views of Rain/Picnic Shelters, whereas (C) depicts a Directional Sign. (Photographs: complements of Carlyon Christian).

\subsection{National and Regional Significance of the Waitukubuli National Trail}

In the long-term, the WNT was envisaged to contribute to Dominica's socioeconomic development during construction, but more so post-construction. Several nationals were employed during the Trail construction phase. As many as 120 persons were engaged during peak construction, as reported by the FWD. The Dominicans who were employed on the WNT construction project supported their families' welfare, paid income taxes, and contributed to the nation's Social Security program.

Being the only island in the English-speaking Eastern Caribbean that has developed a National Trail, Dominica does generate a high level of national pride and nostalgia among a large segment of the local population and Dominicans in the diaspora. The WNT has enhanced Dominica's image and profile in the Caribbean from the perspectives of natural heritage protection, environmental ethics, ecotourism assets, and sustainable environmental management.

Dominica has a sound environmental ethic, one likely to be the most enduring in the Eastern Caribbean. Evidence of Dominica's strong environmental ethics dates back to the 1970s-1990s era when several national sustainable natural resource-related initiatives were pursued, and essential environmental laws were enacted. It may be argued that a few failed timber harvesting and sawmilling operations on the island were the sparks that triggered the initiatives that led to the development of the island's sound environmental ethic. Over the years, Dominica has developed a system of national parks and forest reserves (Table 3). In addition, several other managed and protected ecotourism sites, such as Trafalgar Falls, Titou Gorge, Scotts Head/Soufriere Marine Reserve, and Soufriere Sulphur Springs, are outside the boundaries of the established national parks and forest reserves.

Communities traversed by or are close to the WNT have been encouraged to seize the opportunity to develop support services for the Trail users. Within this framework of entrepreneurship and enhanced skill development, rural community residents have the opportunity to develop micro-enterprises such as bed and breakfast facilities, small restaurants, cultural and artistic performing groups, tour guiding and destination management services, sale of fresh fruits and vegetables, and craft/souvenir outlets. In rural communities where agriculture is on the decline, avenues for other income generation and employment creation sources are critical. Consequently, local government officials responsible for 'WNT impacted communities' have sought to organize and motivate their constituents to capitalize on these potential economic opportunities. Economic activities at the community level, among other things, positively contribute to reduced unemployment and underemployment, reduce rural-to-urban migration, and enhance the quality of life 
and self-esteem of residents. Sound ecosystem management can undoubtedly further the realization of societal values [17].

Table 3. The units of Dominica's national park and forest system.

\begin{tabular}{|c|c|c|c|}
\hline Unit's Name & $\begin{array}{l}\text { Area Ha } \\
\text { (Acres) }\end{array}$ & Year Est. & Remarks/Comments \\
\hline $\begin{array}{l}\text { Central Forest } \\
\text { Reserve }\end{array}$ & $\mathrm{N} / \mathrm{A}$ & 1952 & $\begin{array}{l}\text { First protected area established on } \\
\text { the island. }\end{array}$ \\
\hline $\begin{array}{l}\text { Northern Forest } \\
\text { Reserve }\end{array}$ & $\begin{array}{l}5,476.9 \\
(13,531)\end{array}$ & 1977 & $\begin{array}{l}\text { Approximately } 35 \% \text { of the original } \\
\text { Reserve was annexed and incorporated } \\
\text { into the Morne Diablotin National Park. }\end{array}$ \\
\hline $\begin{array}{l}\text { Morne Trois Pitons } \\
\text { National Park }\end{array}$ & $\begin{array}{c}6,857 \\
(16,940)\end{array}$ & 1975 (July) & $\begin{array}{l}\text { The island's first national park. } \\
\text { Inscribed by UNESCO as a World } \\
\text { Heritage Site in } 1997 .\end{array}$ \\
\hline Cabrits National Park & $531(1313)$ & 1986 & $\begin{array}{l}426 \text { ha ( } 1053 \text { acres) of the park is marine. } \\
\text { A cruise ship berth is located along } \\
\text { southwestern boundary. Contains ruins } \\
\text { of an } 18 \text { th century British garrison and } \\
\text { the largest wetland on the island. Two } \\
\text { hotels have been developed along the } \\
\text { northern and southwestern } \\
\text { boundaries, respectively. }\end{array}$ \\
\hline $\begin{array}{l}\text { Morne Diablotin } \\
\text { National Park }\end{array}$ & 3337 (8242) & $\begin{array}{c}2000 \\
\text { (January) }\end{array}$ & $\begin{array}{l}\text { May have been the first national park } \\
\text { established, globally, in the 21st century. } \\
\text { Prime habitat for the island's two } \\
\text { endemic parrots. }\end{array}$ \\
\hline
\end{tabular}

Based on general observations and discussions with local technocrats, the WNT has helped to engender national pride among the local population, particularly among the youth. This is evidenced by the increased level of interest in and participation in hiking among that segment of the population. The involvement of the youth and their organizations in undertaking trail clean-up and maintenance activities have been unprecedented. The 'community spirit' among some of the communities adjacent to the WNT has been rekindled. Local municipal authorities have also demonstrated their enthusiasm for and support of the National Trail. In partnership with other stakeholders such as FWD, the Hotel and Tourism Association, and the Water Sports Association, and Discover Dominica, the Government has sought to demonstrate the potential socio-economic impact of the National Trail. The WNT is being marketed and promoted regionally and internationally as a 'must see' new, unique, and essential component of Dominica's ecotourism product mix.

Hurricane Maria of 18 September 2017, a category five storm, resulted in extensive devastation of Dominica and the WNT. Understandably, sectors of more critical national and social need such as education, housing, agriculture, communication, and health have attracted and continue to attract more Government attention and external assistance in this post-Hurricane Maria environment. Consequently, aspects of WNT rehabilitation works are still in progress. However, if the momentum and interest generated during the first 36 months following the official opening of the WNT is any guide to go by, indications are that the local population's enthusiasm and visitors' interest in a rehabilitated WNT will be sustained in the short and long-term.

Some level of regional partnership was evident during the planning and implementation of the trail project. The feasibility study was undertaken by a Trinidad and Tobagobased firm, and the trail construction works were contracted to a Martinique-based group. The project's funding was sourced from the BDD, EU, and the French Overseas Department of Martinique.

Caribbean nationals and persons outside the region interested in long-distance hikes now have the opportunity to explore the WNT, along with the breath-taking landscapes 
and the exciting flora and fauna along the route. Dominica has led the way in the Eastern Caribbean in terms of national trail development. The other Caribbean states have the opportunity to benefit from Dominica's experiences. Dominica's Waitukubuli National Trail development success could serve as a motivator for other islands. It is still relatively early in the life of the WNT. However, it is generally accepted that the Trail can make significant social, cultural, and economic contributions to the development of Dominica. If these anticipated benefits are realized, the neighboring islands will be more likely to consider the development of national or long-distance trails.

\subsection{Lessons Learned}

One of the lessons learned from this review and analysis is that Governments in small island-nation environments do not always show respect for citizens' intellectual property rights. Furthermore, citizens whose public statements, philosophy, and political persuasions may differ from those of the ruling administration are likely to be ignored or criticized in such island-settings. This lack of respect for and tolerance of opposing views results in the under-utilization of talented and creative human resources. In the context of this analysis, there is no doubt that the final planning and implementation phases of the WNT could have benefited much from the strategic outlook and visioning of those who conceptualized this significant national project. Granted, the WEF officials could have been more cooperative with the Government, considering that the Government is the ultimate authority/decision-maker in the country. However, the Government should have been more accommodating to WEF in implementing and managing the project. The nation would have been better off with the involvement, participation, and engagement of as many stakeholders as possible in this impactful national project.

Another lesson learned was that civil society has an important role and contribution to make towards the conceptualization and implementation of nationally significant projects in small island-nation settings. The realization of such goals is best achieved by adopting a spirit of the public sector and civil society collaboration, exercised in an atmosphere of mutual respect, trust, tolerance, and commitment. The importance of such a strategy cannot be overemphasized.

Intergovernmental and international agencies generally seek to avoid any appearance of direct interference in countries' internal politics. However, such agencies do have a moral obligation and ethical responsibility to ensure that citizens who defend their intellectual property rights and freedom to criticize the Government are not 'divorced' from the products and outcomes of their creativity and intellect. To many Dominicans, the Government's failure to provide a meaningful and accommodating role for the individual who conceptualized the WNT project, who single-handedly sourced funding to support the feasibility study, and who was instrumental in building initial public support for the project was deemed unacceptable. Thus, the third lesson learned was the need for intergovernmental and international agencies to be more sensitive to human rights violations in the countries where they operate. As far as possible, these external agencies should facilitate respect for human rights in these countries.

\subsection{Future Outlook}

\subsubsection{Strategies}

The long-term goal is to ensure that WNT is effectively managed and maintained to realize the anticipated sustainable socioeconomic impacts. Several strategies are proposed for accomplishing WNT's long-term goal:

1. The concept of 'Adopt-a-Trail Segment', patterned after the 'Adopt-a-Mile' of roadway concept in the developed countries, may be considered. This initiative would be an avenue for fostering and sustaining more youth and community involvement in the WNT project and providing opportunities for the private sector stakeholders (e.g., tour operators, hotel association, the financial sector, the commercial sector, religious, and other groups) to be involved. Appropriate signage acknowledging the 
'Adopt-a-Trail Segment' collaborators could be posted along with information about the relevant trail segment.

2. The appointment of 'Honorary Trail Segment Coordinators' is recommended. These individuals' role could include the monitoring conditions of assigned trail segment, serving as tour guides where necessary, and liaising with and supervising 'Adopta-Trail Segment' group activities to ensure adherence to WNT trail maintenance standards. These Coordinators would also liaise with and advise the WNT Management Unit about relevant trail-related issues and concerns. Although the Trail Segment Coordinators' position would be voluntary, to promote and maintain Coordinators' interest, an annual recognition award ceremony to honor top performers could be considered.

3. The introduction of a 'WNT Passport' is another initiative worthy of consideration. Each page of the proposed minimum 14-page 'WNT Passport' would highlight one trail segment's features and provide for the accommodation of a WNT date-stamp, to be administered either by WNT Management Unit, Segment Coordinators, FWD, or other officially designated representatives. Individuals will qualify for a stamp on successfully hiking the relevant trail segment. The sale of this 'WNT Passport' would serve as a revenue generator and a useful marketing and promotion tool among locals and visitors alike.

4. Dominica could adopt a modification of the UK's 'Trail Register' model. There are four levels or categories: Bronze Level, Silver Level, Gold Level, and Diamond Level in the UK's model. These categories are based on the number of trails/trail segments completed within specified timeframes, by hikers applying to be registered. The ultimate achievement would be to hike all of the National Trail segments as one continuous pedestrian journey, a very demanding challenge [4]. Dominica would have to develop its standards based on the WNT segments, but the UK's experience can serve as a useful guide. Certificates of achievement could be added as another dimension of the proposed 'WNT Register'. Like the 'WNT Passport', the 'WNT Register' has the potential of developing into useful marketing, promotion, and public awareness tools.

5. A reliable and sustainable maintenance funding mechanism and a maintenance schedule must be developed to ensure that WNT hikers continue to have an enjoyable and rewarding experience. Given the national significance and importance of WNT, the Government may wish to consider establishing a designated WNT Maintenance Fund into which private donations would be solicited, and a percentage of WNT ticket sales could be deposited monthly.

6. The skillful development of a 'WNT brand' of a range of memorabilia (e.g., view cards, posters, videos, scarves, key rings, caps, etc.) and competitions/events (e.g., the photograph of the year, the hiker of the year, the Coordinator of the year, WNT Community of the year, etc.) have the potential of generating sustained interest in, significant revenues and promotion for the WNT.

\subsubsection{Research}

Monitoring of ecological impacts along the trail will be necessary. However, following the restoration of the WNT, it would be useful to undertake research to assess residents', community leaders', representatives of tourism sector and civil society, and trail users' perspectives and perceptions about the Trail. Such an investigation will inform and assist the WNT Management Unit in the formulation of appropriate management approaches, environmental education and sensitization strategies, and interpretation requirements along the Trail. This assessment may also present opportunities to expand on some proven environmental education strategies identified by Christian et al. [18] and to establish trail monitoring programs to assess trail conditions [19] and to reduce ecological impacts [20]. Assessment is also likely to provide insights into the Trail's socio-economic impact [21,22]. 
Trail users who are satisfied with the social and ecological trail conditions are more likely to exhibit responsible trail use and behaviors and act as good trail stewards [23]. The proposed assessment will provide insights into users' perceptions about the existence of such trail conditions. Such information will be useful for planning and management purposes. Additional research focusing on the flora, fauna, agritourism and geotourism opportunities, historical and cultural sites, geology and hydrology, and ecosystem diversity and dynamics along the Trail should be pursued.

\section{Conclusions}

The study revealed that several challenges were encountered and overcame during the WNT's development, the first such trail in the Eastern Caribbean. Long-term strategic visioning is not frequently encountered in small, developing island-nation environments. Thus, the conceptualization and successful pursuit of a National Trail development in a climate of high unemployment and other more critical social issues was rather unusual and forward-looking. WEF, the initial advocate and driving force behind the WNT concept, realized that the success of such a project would be dependent on the level of support and partnerships fostered locally and externally. Private landowners, community groups, local authorities, and civil society groups were among non-governmental stakeholders with whom partnerships had to be fostered.

The FWD believes that securing funding and negotiating the difficult Dominican terrain were among the primary challenges in making the project a reality. The Division perceives that the standardization of the quality products and services provided by vendors and service providers to trail users, and the effective monitoring of the sale of trail access passes are likely to be among future challenges. Furthermore, the issues of visitor safety and trail maintenance will pose some future management challenges. Eyler et al. [3] have referenced related safety concerns expressed by community residents because of 'strangers' in the community via the trails. The establishment of the WNT Management Unit, housed in offices at Pond Case, and reporting to the Director of FWD demonstrates the Government's long-term commitment to the project. The Unit is staffed by a Technical Operations Officer who provides direct supervision of a Technical Officer, a Promotion and Resource Development Officer, and a Senior Clerk/Webmaster.

The WNT's rehabilitation and maintenance continue to be the Trail Management Unit's primary focus in this post-Hurricane Maria environment. It will be some time before the entire Trail is restored. However, public officials on the island are hopeful that both local and overseas interest in the WNT will endure during this period of Trail restoration and rehabilitation. Several lessons were learned from the Trail project, lessons that Dominica would be happy to share with its sister Caribbean islands and other Small Island Developing States (SIDS) network members.

There are limitations to this study. One of the obvious limitations is that the analysis was not quantitative and data-driven but rather primarily qualitative. The fact that no other national trail development models in small island-nations were evident in the literature may be considered another limitation, in part because comparisons were not possible. However, this review and analysis have captured the relevant experiences, challenges, and lessons learned regarding Dominica's WNT. Furthermore, management strategies and research initiatives for future consideration have been proposed.

Funding: No external funding was received for this study.

Institutional Review Board Statement: Not applicable.

Informed Consent Statement: Not applicable.

Data Availability Statement: The data presented in this study are available within the article or on request from the corresponding author. 
Acknowledgments: The author is very grateful for the constructive comments and input received from peer reviewers. He is also grateful to Ashton Lugay (Natural Resource Specialist and WNT's First Technical Officer), Eric Hypolite (Forestry Specialist and WNT's Technical Officer), Bernard Wiltshire (Attorney and Former President of WEF), Dominica's Forestry and Wildlife Division, and representatives from several public and civil society agencies on Dominica for their collaboration and insights.

Conflicts of Interest: The authors declare no conflict of interest.

\section{Appendix A}

\section{Waitukubuli National Trail (WNT) Survey-2014}

Your responses to this brief survey on the WNT would be appreciated. Any information shared will be handled in the strictest confidence to protect your identity. This survey will inform an analysis of the WNT which is being conducted by Colmore S. Christian, PhD (Tel. 256-651-2841 \& Email: colmore.christian@aamu.edu). Feel free to contact him for any clarification, deemed necessary. Kindly answer as many questions as possible.

1. What was the total cost of trail construction?

2. Source(s) of funds were (name source and amount of funding)?

3. How did Government gain access/permission to develop trail on private lands? Was this accomplished by way of an SRO or other regulations?

4. Were private landowners compensated for traversing of their lands? If so how? What standards/formulae were used to compute compensation?

5. To the best of your knowledge what was the largest number of Dominicans employed on the National Trail during trail construction?

6. In your opinion, what were the three greatest challenges experienced during trail construction?

7. In your opinion, what are the three most critical challenges experienced since the official opening of the National Trail to the public?

8. What is the current management structure of the WNT?

9. How is the management and maintenance of the WNT currently financed (select boxes as appropriate?
a. [ ] National treasury only
b. [] Private donations only
c. [] User fees only
d. [ ] Combination of (a), (b), and (c)
e. [] Combination of (a) and (c)
f. [ ] Combination of (a) and (b)
g. [ ] Combination of (b), and (c)

\section{References}

1. Interagency Team. USFS/NPS/BLM/FWS Interagency Definition (36 CFR 212.1). Available online: http://www.fs.fed.us/ recreation/programs/trail-management/trail-fundamentals/USFS_Trail_Definitions_04_2007.pdf (accessed on 15 July 2020).

2. Douglass, R.W. Forest Recreation. In Prospect Heights, 5th ed.; Waveland Press, Inc.: Long Grove, IL, USA, 2000.

3. Eyler, A.; Brownson, R.C.; Everson, K.R.; Levinger, D.; Maddock, J.E.; Pluto, D.; Troped, P.J.; Schmid, T.L.; Carnoske, C.; Richards, K.L.; et al. Policy Influences on Community Trail Development. J. Health Politics Policy Law 2008, 33, 407-427. [CrossRef] [PubMed]

4. The Long-Distance Walkers Association (Cited as LDWA). Available online: https://www.ldwa.org.uk/nationaltrails/nt_register. php? (accessed on 22 January 2020).

5. Gilbert, T.L. The National Trails System: What It is and How It Came to Be. Available online: http://www.bcha.org/wp-content/ uploads/2016/07/TheNationalTrailsSystem.pdf (accessed on 15 July 2020).

6. National Trail. The National Trail. Available online: http:/ / www.nationaltrail.co.uk/the-trails (accessed on 20 June 2020).

7. Christian, C.S. Outdoor Recreation and Nature Tourism Related Environmental Impacts in a Tropical Island Setting: Commonwealth of Dominica. Ph.D. Dissertation, Department of Parks, Recreation, and Tourism Management, Clemson University," Clemson, SC, USA, 1996.

8. Evans, P.G.H.; James, A.A. A Guide to Geology, Climate and Habitats (Dominica Nature Island of the Caribbean Series); Ecosystems Ltd.: Brussels, Belgium, 1997. 
9. Geoscience News and Information. Caribbean Islands Map and Satellite Image. Available online: https://geology.com/world/ caribbean-satellite-image.shtml (accessed on 15 July 2020).

10. Government of Dominica ${ }^{1}$. Welcome to the Website of the Waitukubuli National Trail. Available online: http://www. waitukubulitrail.com/ (accessed on 20 May 2020).

11. Government of Dominica ${ }^{2}$. Alignment of Dominica's Waitukubuli National Trail. Available online: http://avirtualdominica. com/images/wnt_map_attractions.jpg (accessed on 15 June 2020).

12. Government of Dominica ${ }^{3}$. The Waitukubuli National Trail's 14 Segments. Available online: http://avirtualdominica.com/ avdquerydetail.cfm?id=1408 (accessed on 20 July 2020).

13. Wiltshire, B. The Waitukubuli Trail. In A Study of the Feasibility of Creating the Waitukubuli National Trail Dominica; CANARI: Laventille, Trinidad and Tobago, 1995; pp. 36-41.

14. Caribbean Natural Resources Institute [cited as CANARI]. In A Study of the Feasibility of Creating the Waitukubuli National Trail, Dominica; CANARI: Laventille, Trinidad and Tobago, 2002.

15. Christian, C.S.; Lacher, T.E., Jr.; Hammitt, W.E.; Potts, T.D. Visitation Patterns and Perceptions of National Park Users: Case Study of Dominica, West Indies. Caribb. Stud. J. 2009, 37, 83-103. [CrossRef]

16. Christian, C.S.; Potts, T.D.; Burnett, G.W.; Lacher, T.E., Jr. Parrot Conservation and Ecotourism in the Windward Islands. J. Biogeogr. 1996, 23, 387-393. [CrossRef]

17. Taylor, P.W. The Ethics of Respect for Nature. Available online: http://wildsreprisal.com/wp-content/uploads/2012/12/TheEthics-of-Respect-for-Nature.pdf (accessed on 18 July 2020).

18. Christian, C.S.; James, A.A.; Charles, R. Environmental Education in the Commonwealth of Dominica: Especially as it relates to Parrot Conservation. J. Environ. Conserv. 1994, 21, 361-364. [CrossRef]

19. Chatterjea, K. Assessment and demarcation of trail degradation in a nature reserve, using GIS: Case of Bukit Timah Nature Reserve. Land Degrad. Dev. 2007, 18, 500-518. [CrossRef]

20. Christian, C.S. Biophysical Impacts to Trees at Protected Sites on the Island of Dominica: Implications for Biodiversity and Conservation. J. Exp. Agric. Hortic. 2012, 1, 41-55.

21. Christian, C.S.; Herbert, B. Perceived Socio-economic, Socio-ecological and Socio-cultural Impacts of the Caribbean's Tourism Sector. Adv. Soc. Sci. Res. J. 2016, 3. Available online: http://scholarpublishing.org/index.php/ASSRJ/article/view/2448 (accessed on 22 December 2020). [CrossRef]

22. Christian, C.S.; Zhang, Y.; Kebede, E. The Socio-economic Contribution of Small and Medium-sized Privately-Owned Outdoor Recreation Enterprises in Alabama-An Exploratory Investigation. Int. J. Bus. Soc. Sci. 2017, 8, 117-125.

23. Peterson, B.A.; Brownlee, M.T.J.; Marion, J.L. Mapping the Relationship between Trail Conditions and Experiential Elements of Long-distance Hiking. Landsc. Urban Plan. 2018, 180, 60-75. [CrossRef] 